\title{
PENGARUH COOPERATIVE PLAY TERHADAP INTERAKSI SOSIAL ANAK KELAS V
}

\author{
Aristina Halawa \\ Jln. Cimanuk No. 20 Surabaya Telp. (031) 5633365
}

\begin{abstract}
ABSTRAK
Kemampuan siswa dalam berinteraksi sosial dapat dikategorikan mejadi dua kelompok, yaitu siswa mampu berinteraksi dengan baik atau pandai bergaul dan siswa yang kesulitan bergaul atau yang tidak bisa berinteraksi dengan baik. Anak yang kesulitan dalam bergaul atau tidak bisa berinteraksi dengan baik memerlukan adanya kegiatan (sarana) agar dapat berinterkasi dengan orang lain yaitu salah satunya dengan bermain. Interaksi sosial dapat ditingkatkan melalui cooperative play karena kegiatan ini dilakukan secara bersama sama. Penelitian ini bertujuan untuk mengetahui pengaruh cooperative paly terhadap interaksi sosial pada anak usia sekolah kelas V di SDN Sawunggaling 1 Surabaya. Desain penelitian yang digunakan metode penelitian one-group pra-post the desaign. Populasi penelitian adalah 25 responden anak usia sekolah, menggunakan total sampling 25 responden. Pengumpulan data menggunakan kuesioner interaksi sosial. Sebagian besar responden memiliki interaksi sosial cukup sebelum dilakukan cooperative play sebanyak 15 orang $(60 \%)$ dan setelah dilakukan cooperative play terdapat sebagian besar responden mengalami peningkatan interaksi sosial baik sebanyak 17 orang (68\%). Analisa data menggunakan uji Wilcoxon didapatkan $\mathrm{p}=0.035$ dimana $\mathrm{p}<0,05$ yang artinya ada pengaruh cooperative play terhadap interaksi sosial anak usia sekolah kelas $\mathrm{V}$ di SDN Sawunggaling 1 Surabaya. Cooperative play dapat direkomendasikan sebagai salah satu terapi bermain pada anak dalam meningkatkan interaksi sosial.
\end{abstract}

\section{Kata kunci: Anak usia sekolah, Interaksi Sosial, Cooperative Play.}

\begin{abstract}
The ability of students in social interaction can be categorized into two groups, namely students are able to interact well or good at socializing and students who have difficulty mingling or who can not interact well. Children who have difficulty in mingling or can not interact well requires the existence of (means) in order to interact with others, one of them by playing. Social interaction can be improved through cooperative play because this activity is done together. The study aims to determine the influence of cooperative play to social interaction in children of school age the fifth grade in elementary school Sawunggaling 1 Surabaya. The research design of this study uses the method of research one-group pra-post the desaign. The research is the children of school age, the total sampling 25 respondents. Gathering data in a questionnaire the social interactions. Most respondents have social interaction just piror to the cooperative the play asa many as 15 people (60\%) and after cooperative the play is most respondents had the increase in social interaction as well as many as 17 people (68\%). Analysis of data using the wilcoxon to $p=0.035$ where $p<0.05$ which means there is influence cooperative the play to social interaction children of school age the fifth grade in elementary school Sawunggaling 1 Surabaya. Cooperative play can be recommended as one play therapy on children in increasing social interaction.
\end{abstract}

Keywords: children of school age, interaction of social, cooperative the play. 


\section{PENDAHULUAN}

Manusia adalah makhluk sosial dan sebagai makhluk sosial manusia memiliki motif untuk mengadakan hubungan dan hidup bersama dengan orang lain, yang disebut dorongan sosial. Manusia membutuhkan hubungan bukan saja dengan individu lain, tetapi juga dengan lingkungan dimana ia berada. Lingkungan mempengaruhi individu dalam mengembangkan, mengingatkan, dan memberikan sesuatu yang ia butuhkan. Dalam hidup bersama itu terjadi hubungan antarmanusia dalam rangka memenuhi kebutuhan hidupnya, sedangkan untuk mencapai keinginan itu perlu diwujudkan dalam bentuk tindakan melalui hubungan timbal balik. Hubungan ini yang disebut interaksi sosial. Interaksi sosial dapat disebut juga proses sosial, dan merupakan syarat utama terjadinya aktivitas-aktivitas sosial (Sunaryo, 2004). Interaksi sosial adalah hubungan antara dua orang atau lebih, sehingga kelakuan individu yang satu mempengaruhi, mengubah, atau memperbaiki kelakuan individu yang lain atau sebaliknya (Ary H. Gunawan, 2000). Syarat terjadinya interaksi sosial adalah adanya kontak sosial (social contact) dan adanya komunikasi (communication) (Sunaryo, 2004). Dilihat dari bentukya interaksi sosial dibagi menjadi 4 yaitu, kerja sama (cooperation), persaingan (competition), pertentangan atau pertikaian (conflict), dan akomodasi atau penyesuaian diri (accomodation) (Soerjono Soekanto, 2010). Interaksi sosial yang tercipta tergantung dari usia yang dimiliki, karena setiap usia memiliki karakteristiknya masing-masing. Seseorang yang memiliki usia dewasa tentu interaksi sosial yang dimiliki berbeda dengan anak-anak (Yudiharyanto, 2015). Anak usia sekolah adalah anak pada usia 6-12 tahun, yang artinya sekolah menjadi pengalaman inti anak. Pada usia sekolah, anak dianggap mulai bertanggung jawab atas perilakunya sendiri dalam hubungan dengan orang tua mereka, teman sebaya, dan orang lainnya (Wong, 2008). Pada usia-usia tersebut anak mulai mengembangkan hubungan pertemanan, anak akan menyadari kebutuhannya untuk diterima dalam lingkungan teman sebayanya. Kesempatan anak untuk berinteraksi dengan teman sebaya pun menjadi lebih banyak. Tetapi pada tahap ini ada beberapa penyebab anak sulit untuk berinteraksi hal ini dapat disebabkan oleh karena mereka memiliki kepribadian yang tertutup bisa disebabkan oleh faktor genetik, memiliki kepribadian yang cenderung kaku kurang bisa menyesuaikan diri dengan lingkungan, HDR atau minder, tidak percaya diri, fobia sosial karena adanya faktor traumatik akan kejadian dimasa lalu, lingkungan yang tertutup mengakibatkan anak tidak memiliki kesempatan bergaul dengan orang-orang sekitar, memiliki gangguan emosional menyebabkan seseorang kesulitan mengontrol emosi dan akhirnya dijauhi orang lain, serta memiliki kebiasaan-kebiasaan yang telah tertanam dibawah sadar yaitu rasa minder, malu, tidak percaya diri sehinga dapat membuat anak tersebut lama kelamaan akan mengalami depresi pada anak. Dalam pandangan ini menunjukkan anak usia sekolah memerlukan adanya interaksi sosial dengan orang lain dalam kegiatan-kegiatan yang dilakukan secara bersama-sama. Kegiatan ini dapat dilakukan melalui kegiatan bermain. Pengalaman bermain dapat menjadi sarana untuk perkembangan sosial anak terutama jenis bermain sosial atau yang sering dikenal dengan Cooperative Play (Supendi dan Nur Hidayat, 2007). Cooperative play merupakan permainan yang dimainkan secara berkelompok yang ditandai dengan adanya kerjasama atau pembagian tugas dan peran antara anak yang terlibat dalam permainan untuk mencapai suatu tujuan tertentu (Subaida, 2016). Pengalaman ini mengajarkan anak untuk mendapatkan keterampilan sosial yang dibutuhkan untuk beriteraksi dengan orang lain.

Data anak usia sekolah dasar menurut Indonesia Education Satatistics in Brief tahun 2014/2015. Sekolah Negeri 132,609 jiwa, Sekolah Swata 14.904 jiwa. Berdasarkan studi pendahuluan yang penulis lakukan di SDN Sawunggaling I Surabaya pada siswa kelas V yang berjumlah 25 siswa, pada saat jam istirahat ada 13 siswa tampak sedang bermain bersama sedangkan 5 siswa lainnya terlihat tidak bermain bersama teman-temannya yang lain, dimana ada 2 siswa hanya melihat saja, ada 3 siswa yang terlihat sibuk menghabiskan waktunya dengan mengerjakan tugas sendiri di ujung kelas, 2 siswa tampak duduk menyendiri. Berdasarkan hasil penelitian Subaida (2016) tentang hubugan Cooperative Play perkembangan anak usia prasekolah di taman kanak-kanak negeri Pembina Maesan Kabupaten Bondowoso, hasilnya bahwa anak dengan Cooperative Play yang kooperatif berpeluang 15 kali untuk memiliki 
perkembangan yang tercapai. Penelitian Yudihartono (2015), hubungan intensitas Cooperative Play dengan keterampilan sosial siswa kelas tinggi sekolah dasar se-gugus 4 Kecamatan Pleret Bantul Yogyakarta, hasil penelitian dikatakan bahwa siswa memiliki intensitas Cooperative Play yang tinggi maka mempunyai keterampilan sosial yang tinggi begitu juga sebaliknya. Peneliti Ira Rahmawati (2010), Cooperative Play mempengaruhi interaksi sosial anak dengan gejala keperibadian introvert di SDN Kandangsari III/278 Surabaya, hasil penelitian menunjukkan bahwa aktivitas bermain sosial: Cooperative Play mampu meningkatkan interaksi sosial anak dengan kepribadian introvert.

Interaksi sosial dapat timbul karena adanya beberapa faktor yang mempengaruhi yaitu tempat tinggal individu, norma-norma sosial yang mengatur kelompok, tujuan dari masing-masing individu, kedudukan individu dalam situasi sosial, serta masalah yang terjadi pada masing-masing individu. Masalahmasalah yang sering tejadi dalam interaksi sosial nantinya akan menyebabkan anak sulit untuk berinteraksi hal ini dapat disebabkan oleh karena mereka memiliki kepribadian yang tertutup kurang bisa menyesuaikan diri dengan lingkungan, tidak percaya diri, selain itu lingkungan juga mempengaruhi anak untuk tidak berinteraksi seperti semua permainan disediakan orang tua karena orang tua lebih senang anaknya bermain dirumah sendiri dari pada diluar rumah. Akibatnya anak tidak bisa belajar cara mengatasi konflik, sehingga ketika ia harus menghadapi kenyataan hidup yang mungkin baginya berat maka anak akan tidak memiliki koping mekanisme yang adaptif hal ini dapat terlihat dimana banyak anak-anak yang melakukan upaya bunuh diri untuk suatu masalah yang sebenarnya ringan salah satunya ialah gagal dalam ujian. Untuk menghindari dari hal -hal yang berkaitan dengan masalahmasalah interaksi sosial anak usia sekolah maka masalah ini dapat diminimalkan resikonya dengan kegiatan bermain bersama (Cooperative Play). Cooperatve play dapat berpengaruh pada interaksi sosial anak usia sekolah karena berhubungan dengan basic life skill, seperti keterampilan berkomunikasi, bersosialisasi, bekerjasama, dan bernegosiasi dalam kelompok (Supendi, 2007).

Interaksi sosial dapat dilakukan dengan berbagai cara salah satunya adalah Cooperatie
Play. Cooperative play di tandai dengan adanya interaksi antar anak untuk berbagi tugas, berbagi peran, dan mencapai tujuan yang diinginkan (Yudiharyanto, 2015). Hurlock menyebutkan bahwa salah satu jenis permainan yang mampu memotivasi perkembangan emosi dan sosial anak adalah permainan yang bernuansa sosial (Hartini, 2000). Salah satu permaiannya Cooperative Play (bermaian bersama) ialah permaianan Ular Naga yang dimana permainan ini membutuh kerjasama dengan yang lainnya. Semakin sering anak melakukan kegiatan Cooperative Play (bermain bersama) maka anak akan mampu mewujudkan cita-cita atau tujuan tertentu baik bersifat sosial atau kelompok, meningkatkan kualitas kompetensi diri, membangun solidarita dalam kehidupan bersosial di masyarakat.

\section{BAHAN DAN METODE}

Desain penelitian yang digunakan dalam penelitian ini adalah Pra-Eksperimen dengan menggunakan one-group pra-post test desaign (rencana pra-pascates dalam satu kelompok). Tipe penelitian ini adalah menggungkapkan hubungan sebab akibat dengan cara melibatkan satu kelompok subjek. Kelompok subjek diobservasi sebelum dilakukan intervensi, kemudian diobservasi lagi setelah intervensi (Nursalam, 2016).

Populasi dalam penelitian ini adalah seluruh anak kelas V di SDN Sawunggaling 1 Surabaya, dengan jumlah 25 Siwa/Siswi dengan menggunakan total sampel pada penelitian ini adalah seluruh Siwa/Siswi kelas V SDN Sawunggaling 1 Surabaya sejumlah 25 siswa. Teknik sampling yang digunakan adalah Total sampling.

Variabel bebas (Independent) dalam penelitian ini adalah Cooperative Play: Permainan Ular Naga. Variabel Dependent (terikat) dalam penelitian ini adalah Interaksi Sosial pada anak kelas $\mathrm{V}$ di SDN Sawunggaling 1 Surabaya.

Instrument pada penelitian ini yaitu dengan kuesioner. Kuesioner ini bertujuan untuk mengetahui kemampuan anak usia sekolah terhadap interaksi sosial sebelum. Instrumen untuk cooperative play: permainan ular Naga berupa modul permainan Ular Naga.

Analisa data untuk pengaruh cooperative paly terhadap interaksi sosial anak kelas V di SDN Sawunggaling 1 Surabaya menggunakan uji Wilcoxon. 
HASIL

Karakteristik respoden berdasarkan hasil rekapan data demografi yang meliputi usia, jenis kelamin, pekerjaan orang tua, dan pendidikan orang tua.

Tabel 1.Karakteristik Responden Berdasarkan Usia Di Kelas V SDN Sawunggaling 1 Surabaya,

\begin{tabular}{cccc}
\hline No. & Usia & Jumlah & $\begin{array}{c}\text { Prosentasi } \\
(\mathbf{\%})\end{array}$ \\
\hline 1. & $\begin{array}{c}10-11 \\
\text { tahun }\end{array}$ & $\begin{array}{c}13 \\
\text { orang } \\
12\end{array}$ & $52 \%$ \\
2. & $\begin{array}{c}12-13 \\
\text { tahun }\end{array}$ & $\begin{array}{c}12 \\
\text { orang }\end{array}$ & $48 \%$ \\
\hline \multicolumn{2}{c}{ Total } & $\begin{array}{c}\mathbf{2 5} \\
\text { orang }\end{array}$ & $\mathbf{1 0 0 \%}$ \\
\hline
\end{tabular}

Berdasarkan tabel 5.1 menunjukkan bahwa paling banyak responden berusia 10-11 tahun yaitu sebanyak 13 siswa (52\%).

Tabel 2. Karakteristik Responden Berdasarkan Jenis Kelamin di kelas V SDN Sawunggaling 1 Surabaya,

\begin{tabular}{cccc}
\hline No. & $\begin{array}{c}\text { Jenis } \\
\text { Kelamin }\end{array}$ & Jumlah & $\begin{array}{c}\text { Prosentasi } \\
\mathbf{( \% )}\end{array}$ \\
\hline 1. & Laki-laki & $\begin{array}{c}15 \\
\text { orang } \\
10\end{array}$ & $60 \%$ \\
2. & Perempuan & $\begin{array}{c}10 \\
\text { orang }\end{array}$ & $40 \%$ \\
\hline & Total & $\begin{array}{c}\mathbf{2 5} \\
\text { orang }\end{array}$ & $\mathbf{1 0 0 \%}$ \\
\hline
\end{tabular}

Berdasarkan tabel 5.2 menunjukkan sebagian besar responden berjenis kelamin laki-laki yaitu sebanyak 15 siswa $(60 \%)$.

Tabel 3. Karakteristik Berdasarkan Pekerjaan Orang Tua Responden Di Kelas V SDN Sawunggaling 1 Surabaya

\begin{tabular}{cccc}
\hline No. & $\begin{array}{c}\text { Pekerjaan } \\
\text { Orang } \\
\text { Tua }\end{array}$ & Jumlah & $\begin{array}{c}\text { Prosentasi } \\
(\mathbf{\%})\end{array}$ \\
\hline 1. & PNS & - & - \\
2. & Wirausaha & 5 orang & $20 \%$ \\
3. & $\begin{array}{c}\text { Pegawai } \\
\text { Swasta }\end{array}$ & $\begin{array}{c}12 \\
\text { orang }\end{array}$ & $48 \%$ \\
& Tidak & 1 orang & $4 \%$ \\
4. & Bekerja & orang & $28 \%$ \\
5. & Lain-lain & 7 orang \\
\hline & Total & $\mathbf{2 5}$ & $\mathbf{1 0 0 \%}$ \\
\hline
\end{tabular}

Berdasarkan tabel 3 menunjukkan paling banyak pekerjaan orang tua responden yaitu sebanyak 12 orang $(48 \%)$.

Tabel 4.Karakteristik Berdasarkan Pendidikan Orang Tua Responden Di Kelas V SDN Sawunggaling 1

Surabaya,

\begin{tabular}{|c|c|c|c|}
\hline \multirow[b]{2}{*}{ No. } & \multicolumn{2}{|l|}{ Pendidikan } & \multirow[b]{2}{*}{$\begin{array}{l}\text { Prosentasi } \\
\quad(\%)\end{array}$} \\
\hline & $\begin{array}{c}\text { Orang } \\
\text { Tua }\end{array}$ & Jumlah & \\
\hline 1. & SD & 6 orang & $24 \%$ \\
\hline 2. & SMP & 3 orang & $12 \%$ \\
\hline 3. & SMA & $\begin{array}{c}13 \\
\text { orang }\end{array}$ & $52 \%$ \\
\hline 4. & $\begin{array}{l}\text { Perguruan } \\
\text { Tinggi }\end{array}$ & 3 orang & $12 \%$ \\
\hline & Total & $\begin{array}{c}25 \\
\text { orang }\end{array}$ & $100 \%$ \\
\hline
\end{tabular}

Berdasarkan tabel 5.4 menunjukkan sebagian besar pendidikan orang tua responden yaitu sebanyak 13 orang (52\%).

Tabel 5.Tabulasi silang distribusi data frekuensi interaksi sosial anak kelas V

sebelum dan setelah dilakukan cooperative play di SDN

Sawunggaling 1 Surabaya

\begin{tabular}{lcccc}
\hline $\begin{array}{r}\text { Cooper } \\
\text { ative } \\
\text { Play }\end{array}$ & \multicolumn{2}{c}{ Pre } & \multicolumn{2}{c}{ Post } \\
$\begin{array}{c}\text { Sebel } \\
\text { um }\end{array}$ & $\begin{array}{c}\text { Prosen } \\
\text { tasi } \\
(\%)\end{array}$ & $\begin{array}{c}\text { Setel } \\
\text { ah }\end{array}$ & $\begin{array}{c}\text { Prosen } \\
\text { tasi } \\
(\%)\end{array}$ \\
$\begin{array}{l}\text { Interak } \\
\text { si }\end{array}$ & & & & \\
Sosial & & & & \\
\hline \multicolumn{1}{c}{ Baik } & 10 & $40 \%$ & 17 & $68 \%$ \\
Cukup & 15 & $60 \%$ & 8 & $32 \%$ \\
Kurang & 0 & $0 \%$ & 0 & $0 \%$ \\
\hline \multicolumn{1}{c}{ Total } & $\mathbf{2 5}$ & $\mathbf{1 0 0 \%}$ & $\mathbf{2 5}$ & $\mathbf{1 0 0 \%}$ \\
\hline Hasil Uji statisticWilcoxon $\mathbf{p}=\mathbf{0 , 0 3 5}$ \\
\hline
\end{tabular}

Bersadarkan tabel 5 dapat diketahui bahwa hasil penelitian interaksi sosial pada anak kelas V di SDN Sawunggaling 1 Surabaya sebagian besar memiliki interaksi sosial cukup saat sebelum dilakukan cooperative play sebanyak 15 siswa/siswi (60\%). Sedangkan saat setelah dilakukan terapi cooperative play didapatkan peningkatan interaksi sosial pada responden sebanyak 17 siswa/siswi (68\%) dengan kategori interaksi sosial baik. Kemudian hasil dari data tabulasi silang sebelum dan setelah 
dilakukan terapi cooperative play, hasil tersebut dianalisis meggunakan uji Wilcoxon melalui program SPSS dengan derajat kemaknaan $\mathrm{p}<\alpha(0,05)$, dan didapatkan tingkat signifikan sebesar $\mathrm{p}=0,035$ maka $\mathrm{H}_{1}$ diterima, disimpulkan bahwa ada pengaruh cooperative play terhadap interaksi sosial anak kelas V di SDN Sawunggaling 1 Surabaya.

\section{PEMBAHASAN}

Berdasarkan tabel 5. data karakteristik interaksi sosial anak kelas $\mathrm{V}$ sebelum dilakukan cooperative play dari 25 responden terdapat 15 orang $(60 \%)$ memiliki interaksi sosial cukup, 10 orang (40\%) memiliki interaksi sosial baik. Hal ini berarti bahwa sebagian besar responden sebelum dilakukannya cooperative play memiliki interaksi sosial cukup sebanyak 15 orang $(60 \%)$. Menurut peneliti sebelumnya Maya Yuliani, (2016) interaksi sosial dikatakan cukup apabila siswa belum dapat berinteraksi atau bergau secara optimal, dan belum dapat berhubungan dengan teman, masyarakat lingkungan sekolah maupun saat dalam proses belajar mengajar. Berdasarkan hasil penelitian yang dikaitkan dengan teori maka terdapat kesamaan antara fakta dengan teori yang ada. Menurut peneliti hal ini disebabkan karena, masih banyak dari mereka yang membentuk kelompok-kelompok dalam kelas tersebut. Hal ini terlihat sangat jelas pada saat jam istirahat, dimana mereka terlihat bermain, makan, bersenda gurau dengan teman-teman kelompoknya sedangkan pada anak-anak yang tidak memiliki kelompok atau tidak dalam kelompok tersebut mereka lebih memilih untuk berdiam diri dan mencari kesibukan sendiri, serta mereka mengatakan lebih nyaman sendiri dari pada harus ikut bergabung dengan kelompok tersebut dan anak-anak tersebut terlihat pasif dalam kelas mereka. Hal tersebut juga didukung oleh teori Harlock dimana ciriciri siswa yang mengalami interaksi sosial cukup ialah adanya hambatan atau kegagalan dalam menyesuaikan diri dengan situasi sosial dilingkungannya hal ini juga nampak dalam bentuk sikap dan perilaku yang cenderung negatif, seperti anak akan berperilaku mengabaikan pelajaran, memiliki sifat yang agresif, perasaan tidak aman, kurang mau bergaul secara sosial, pasif dalam kelompok, dan bergantung pada orang lain bila melakukan suatu tindakan. Sehingga didapatkan hasil sebagian besar interaksi sosialnya cukup sebelum diberi cooperative play. Monk dkk (1994) mengatakan dimana faktor-faktor yang dapat mempengaruhi interaksi sosial pada anak yaitu: keadaan sekeliling (lingkungan), jenis kelamin, serta pekerjaan orang tua. Faktor-faktor tersebut saling berkaitan satu sama lain sehingga dapat mempengaruhi suatu interaksi sosial anak. Dengan kata lain semakin baik faktor-faktor yang mempengaruhi interaksi sosial anak maka semakin baik pula kemampuan anak dalam berinteraksi.

Berdasarkan data yang diperoleh dari tabel 2. dapat diketahui sebagian besar responden berjenis kelamin laki-laki sebanyak 15 orang (60\%). Menurut Hurlock (2004), anak perempuan cenderung lebih memilih dalam hal berteman. Sedangkan pada anak laki-laki lebih mudah berteman dengan siapapun. Berdasarkan hasil penelitian yang dikaitkan dengan teori maka terdapat kesenjangan antara fakta dengan teori yang ada. Menurut peneliti hal ini disebabkan karena, walaupun sebagian besar responden bejenis kelamin laki-laki tetapi mereka masih berada dalam tahap perkembangan yang lebih memilih perhatian kepada teman sekelompoknya. Sehingga didapatkan hasil sebagian besar interaksi sosialnya masih dalam kategori cukup sebelum dilakukan cooperative play.

Berdasarkan data gambaran umum yang diperoleh peneliti, sekolah memiliki fasilitas lapangan bermain. Menurut Monk, dkk (1994) seperti tersedianya faktor lingkungan seperti fasilitas lapangan bermain. Maka dapat menunjang kemampuan anak untuk berinteraksi dengan teman sebayak-banyaknya. Berdasarkan hasil penelitian yang dikaitkan dengan teori maka terdapat kesenjangan antara fakta dengan teori yang ada. Menurut peneliti hal ini disebabkan karena, walaupun tersedianya fasilitas lapangan bermain yang dapat digunakan untuk semua siswa/siswi, tetapi jika tidak ada niat dan minat dari siswa/siswi tersebut untuk bermain bersama maka fasilitas yang tersedia tidak digunakan secara maksimal. Sehingga didapatkan hasil sebagian besar interaksi sosial cukup sebelum dilakukan cooperative play.

Berdasarkan penjelas dari pembahasan interaksi sosial sebelum dilakukan cooperative play dari faktor interaksi sosial berdasarkan jenis kelamin juga dapat memicu untuk meningkatakan interaksi sosial cukup, 
lingkungan di sekitar sekolah, dan pekerjaan orang tua. Sehingga sebagian besar responden memiliki kategori interaksi sosial cukup sebelum dilakukan terapi cooperative play.

Berdasarkan data yang diperolah penelitian tabel 5. Sebagiana besar responden yang memiliki interaksi sosial dalam kategori baik sebanyaka 17 orang (68\%). Hasil tersebut menunjukkan bahwa telah terjadi peningkatan setelah dilakukan terapi cooperative play. sedangkan sebagian besar responden yang memliki interaksi sosial dalam kategori cukup sebelum sebanyak 10 orang (40\%). Menurut Sugianto, (2001) cooperative play atau bermain bersama merupakan permainan secara berkelompok yang ditandai dengan adanya kerjasama atau pembagian tugas dan pembagian peran antara anak yang terlibat dalam permainan untuk mencapai suatu tujuan tertentu. Berdasarkan hasil penelitian bila dikaitkan dengan teori yang ada maka terdapat kesesuaian antara fakta dan teori. Menurut peneliti hal ini disebabkan oleh karena bentukbetuk interaksi sosial terwujud dalam cooperative play diantaranya kemampuan anak dalam bermain bersama yaitu anak mampu bekerja sama, berkomunikasi, berinteraksi dengan teman-temannya, mampu mengontrol emosi, mampu bersaing dengan sprotif, mampu menerima kekalahan dalam permaianan. Sehingga didapatkan hasil sebagian besar memiliki interaksi sosial baik setelah dilakukan cooperative play.

Berdasarkan data tabel 1. dapat diketahui bahwa sebagian besar responden berusia 10-11 tahun sebanyak 13 orang (52\%). Menurut Harlock, (dalam Musfirah, 2013) indikator perkembangan sosial anak usa 10-11 tahun kerja sama, persaingan yang sehat, kemauan berbagi atau (sharing), simpati, empati, mau berhubungan dan berkomunuikasi dengan orang lain. Berdasarkan hasil penelitian bila dikaitkan dengan teori maka didapatkan kesesuaian antara fakta dengan teori yang ada. Menurut peneliti hal ini walaupun anak masih dalam usi 10-11 tahun, tetapi mereka mampu menyesuaikan diri mampu bekerja sama dengan baik, memiliki kemampuan komunikasi yang baik serta megerti apa yang dikatakan orang lain. Sehingga didapatkan hasil sebagian besar interaksi sosial menjadi baik setelah dilakukan cooperative play.

Berdasarkan data tabel 4 . dapat diketahui bahwa sebagian besar tingkat pendidikan orang tua responden ialah SMA sebanyak 13 orang (52\%). Menurut Dariyo, (2004) tingkat pendidikan orang tua akan mempengaruhi kemampuan orang tua dalam mendidik anaknya. Semakin tinggi tingkat pendidikan orang tua maka semakin baik pula kemampuan orang tua dalam mendidik anaknya. Berdasarkan hasil penelitian yang dikaitkan dengan teori maka terdapat kesamaan antara fakta dan teori yang ada. Menurut peneliti hal ini menunjukkan bahwa semakin tinggi pendidikan orang tua maka semakin banyak hal yang akan diajarkan pada anak mereka salah satunya ialah bersosialisasi. Hal ini didukung oleh Soetajiningsih (2002) dengan pendidikan yang baik maka orang tua dapat menerima segala informasi dari luar terutama tentang cara pengasuhan anak yang baik, bagaimana menjaga kesehatan anak dan bagaimana memberikan pendidikan pada anak. Sehingga didapatkan hasil interaksi sosial anak baik setelah dilakukan cooperative play.

Dalam melakukan cooperative play atau bermain bersama tedapat kerja sama yang baik yang dilakukan oleh responden dapat membantu meningkatkan interaksi sosial mereka, sehingga mampu mencapai tujuan yang diinginkan bersama. Kemampuan mereka dalam bermain juga dapat menunjang aspek fisik, dimana gerakan-gerakan tubuh akan membuat anak menjadi lebih bugar, sehingga otot-otot akan tumbuh dengan maksimal; aspek sosial, meningkatkan kemampuan anak untuk berinteraksi dan berkomunikasi sehingga mendorong terbentuknya pertemanan; aspek emosi, dimana anak mampu melepaskan perasaan tegang dan tekanan yang dialaminya. Menurut Musfiroh (2005) mengungkapkan bahwa bermain membantu anak menguasi konflik dan trauma sosial sekaligus membantu perkembangan emosi yang sehat dengan menawarkan kesembuhan rasa sakit dan kesedihan, maka mengatasi masalah dalam kehidupan. Kegiatan cooperative play akan membuat anak sadar akan kelebihan dan kekurangan dirinya. Anak akan lebih percaya diri dan mempu meghargai orang lain sehingga hal tersebut akan membantu kebutuhan tersebntukknya kepribadian.

Namun, keberhasilan cooperative play ini juga tidak lepas dari kemauan dan minat dari responden untuk mengikuti kegiatan yang diberikan saat dilakukan intervensi, seperti tidak ada perbedaan antara laki-laki dan perempuan dan kesempatan bersama saat 
sebelum bermaian, harus ada komunikasih yang baik antar teman, tidak ada konflik saat bermain, yang paling penting yang responden harus ketahui pentingnya cooperative play ini adalah dapat membantu mereka untuk saling berinteraksi dan bersosialisasi dengan siapapun, kapanpun, dan dimanapun mereka berada serta memperluas pengalaman, dan pengetahuan dalam hidup di masyarakat yang ada disekelilingnya.

\section{SIMPULAN DAN SARAN Simpulan}

Cooperative Play atau bermaina bersama dapat meningkatkan interaksi sosial anak. Cooperative play dapat direkomendasikan sebagai salah satu terapi bermain pada anak dalam meningkatkan interaksi sosial.

\section{Saran}

Dengan adanya penelitian ini, responden diharapkan mampu melakukan cooperative play (bermain bersama) di lingkungan sekolah maupun di lingkungan masyarakat untuk meningkatkan interaksi sosial anak

Diharapkan dengan adanya penelitian ini, para bapak/ibu Guru khususnya pada Guru olahraga dapat menggunakan dan melakukan cooperative play sebagai salah satu metode tambahan materi untuk meningkatkan interaksi sosial siswa/siswinya.

Dengan penelitian ini diharapkan bisa dijadikan sebagai tambahan materi pada keperawatan anak, khususnya mengenai cara meningkatkan interaksi sosial anak. Mahasiswa dapat menggunakan cooperative play dalam intevensi keperawatan anak.

\section{DAFTAR PUSTAKA}

Ahmadi, Abu dan Joko Tri Pasetya. 2005. Startegi BelajarMengajar. Yogyakarta: PustakaBelajar.

Demita. 2012. Psikologi Perkembangan Peserta Didik. Bandung: Rosda Karya

Firmansah, Andi dan Rodlo Septy. Psikososial. Malang: UMM.

Gunarsa, Singgih. 2004. Psikologi Sosial. Bandung: PT. Refika Aditama. (hal: 75)

\begin{tabular}{l}
.2008. Psikologi \\
\hline Perkembangan Anak dan Remaja. \\
Jakarata: Gunung Mulia. (hal: 15).
\end{tabular}

Hidayah, Rifa. 2009. Psikologi pengasuh anak. Malang: UIN-Malang. (hal: 64).
Hurlock, Elizabeth B. 1978. Perkembangan Anak Jilid 1 Edisi Keenam. Jakarta :Penerbit Erlangga.

Monk, dkk. 1994. Psikologi Perkembangan. Yogyakarta: University Press. (hal: 125).

Nanda. 2014. Bermaindan Perkembangan Anak Usia 6-12 Tahun. http://www.gemalaananda.sch.id/2014/0 6/02/bermain-dan-perkembangan-anak6-12-tahun/, diakses pada tanggal 06 Juni 2017, pukul 15.22 WIB.Nottoamedji, 2010. Metodelogi Penelitian Kesehatan. Jakarta: Anggota IKAPI.

Nursalam. 2016. Metodologi Penelitian Ilmu Keperawatan: Pendekata Praktis. Jakarta: Salemba Medika. . 2008. Konsep dan Penerapan Metodologi Penelitian Ilmu Keperawatan. Jakarta: SalembaMedika. (Hal: 80-226).

Nurastuti, et al. 2012. Pengaruh permainan Tradisional Benteng terhadap Interaksi Sosial Anak Panti Yatin Hajah Maryam Kalibeber Wonosobo. Jurnal wacana. psikologi. fk. uns. ac.id/index.php/wacana/article/view/83, diakses pada tanggal 13/06/2017, pukul 2.14 WIB.

Purwanti, Endah. 2012. Jurnal Upaya Meningkatkan kemampuan interaksi sosial melalui metode bermain peran pada anak Play Group MataharikungemplakBoyolali.eprints.ums.ac.id/1 9226/1/02._HALAMAN_DEPAN.pdf, diakses pada tanggal 14/06/2017, pukul $08.31 \mathrm{WIB}$.

Rahmawati, Ira et al. 2010. Jurnal Cooperative Play Mempengaruhi Interaksi Sosial Anak Dengan Gejala Kepribadian Introvert.www.ira_cantik@yahoo.com. Fakultas Keperawatan Universitas Airlangga Surabaya.

Satrock, John W. 2012. Psikologi Pendidikan. Jakarta: Salemba Medika. (hal: 97 dan 114).

Subaida. 2016. Jurnal Perkembangan anak usia prasekolah di taman kanak-kanak Negeri Pembina Maesa Kabupaten Bondowoso.

Sunaryo. 2004. Psikologi Untuk Keperawatan. Jakarta: Penerbit Buku Kedokteran. EGC. 
Supendi, P dan Nurhidayat. 2007. Fun Game 50 Permainan Menyenangkan di Ondoordann Outdoor. Jakarta: Penebar Plus, hlm 7-80.

Soetjiningsih. 1998. Tumbuh Kembang Anak. Jakarta: ECG. (Hal: 105.191).

Tedjasaputra, Mayke S. 2005. Bermain, Mainan, dan Permainan untu Pendidikan usia dini. Jakarta : Gramedia

Wong, D, dkk. 2009. Buku Ajar KeperawatanPediatrik. Volume 1. Jakarta: Penerbit Buku Kedokteran EGC.

Yudiharyanto. 2015. Hubungan intensitas cooperative play dengan keterampilan Sosial kelas tinggi sekolah dasar segugus iv Kecematan Pleret Bantul.Yogyakarta:eprints.uny.ac.id/208 22/1/SKRIPSI_Yudiharyanto_11108244 061_PGSD_2011.pdf, diakses pada tanggal 31 Juni 2017 pukul 18.00 WIB.

Yuliani Maya, 2016. Pengaruh interaksi sosial terhadap terbentuknya kelompokkelompok pergaulan di SMK Nusantara Desa Madukoro Kecamatan Kotabumi Kabupaten Lampung Utara, http://www.digilib.unila.ac.id, diakses pada tanggal 27 Mei 2017 pukul 13.00 WIB. 